\title{
Design of a Simplified 7 Level Inverter
}

\author{
Mohd Abdul Kareem, Maheswari.E, Pavani Parachuri, Durgam Srinivas
}

\begin{abstract}
In this paper a multi-stage inverter new configuration to growth the quantity of tiers switching voltage the usage of less studied. The proposed inverter includes H-bridge cells in conjunction with an active rectifier and switches. Using PWM modulation technique and collective enter dc supply capacitor series. The validity of the inverter is projected completed using MATLAB software program simulation tools and additionally the applicable theoretical evaluation executed. Capacitor voltage imbalance conquer by way of presenting a modified switching method.
\end{abstract}

Keywords Multi-stage, voltage unbalance, THD.

\section{INTRODUCTION}

General study of a multilevel converter is to utilize the electricity semiconductor switches are connected to the low dc voltage source to compensate for the voltage waveform stair case close. High first-rate output voltage, reduced voltage stress at the switching device power and higher performance. More currently, this dc-ac kind of multilevel acquired wonderful attention from business use electric home equipment that lead look at thought inverter. Secondary converter concept is to supply the identical output voltage of sinusoidal kinds. Output voltage degree of great this is green, which defines the deformation of harmonics (THD) and coffee-voltage exchange with respective times of strain and measurement minutes from the clear out output.

H-bridge cellular, which has lots of variety of switches and freelance ++ enter dc voltage supply. In one exceeds the one in every of the solutions to scale back the amount of parts in CHB is to apply asymmetric dc voltage supply [8], [9]. After a dc voltage is scaled in 3 watts, it'll maximize the amount volt output stage. However, they'll boom the direct contemporary voltage supply is casual to come up with the output voltage stage is better. The disadvantage to finish the electrical converter tool structure using energy flows brought in [10]. It also uses a aggregate of normal volt supply to make the shape of the output voltage. Mostadvantageous action inside the future is that it simplest employs one dc voltage supply. However, the electrical device flows create huge structures as a result of the operation at very low frequencies. To alleviate these drawbacks, the exploitation of four power converter shape watt balanced deliver changed into delivered in [11]. This

Revised Manuscript Received on September 14, 2019.

Mohd Abdul Kareem, Associate Professor, Department of EEE, Siddhartha Institute of Technology \& Sciences, Narapally, Ghatkesar, Hyderabad, Telangana, India.

Maheswari.E, Associate Professor, Department of EEE, Sri Sairam Institute of Technology, Chennai, Tamilnadu, India.

Pavani Parachuri, Assist. Prof, Department of EEE, Siddhartha Institute of Technology \& Sciences, Narapally, Ghatkesar, Hyderabad, Telangana, India

Durgam Srinivas, Assist. Prof, Department of EEE, Siddhartha Institute of Technology \& Sciences, Narapally, Ghatkesar, Hyderabad, Telangana, India device is usually tailored and evolved from the CHB. In [12], packed gadget U-available cellular. However, increasetransfer losses when growing any voltage degree for passing a cutting-edge of 3 rotating switching element in an man or woman stage.Moreover, massive ripple volts produced across the capacitor, however the capacitor 5000 $\mathrm{uF}$ ranked. The device uses a two-way switch with a capacitor collection connected. Mathematically, they are able to produce a variety of greater than the output voltage stage of more than a hundred twenty five stages with fewer additives.However, every capacitor mutual want dc-dc converter to gain a dc voltage supply. It has the characteristics of accurate; thus, it is simple to extend the excessive voltage degree.

\section{PROPOSED LEVEL SEVEN SIMPLE PWM INVERTER}

Picture. 1 shows the real circuit configuration 7- Pulse Width Modulation stage converter. Having a single dc voltage source, that is divided into three capacitors connected in series. Imagine all of the additives are best. Each capacitor voltage is VDC / three. Then, we will acquire a seven-degree output voltage waveform, 2VDC / three, VDC / 3, 0, -Vdc / 3, -2Vdc / three, and -Vdc. Switch in cells $\mathrm{H}$-bridge ( $\mathrm{S} 1$ to $\mathrm{S} 4$ ) are working to determine the polarity of the out-put volt with a most voltage level, ie Vdc (or $-\mathrm{Vdc}$ ). Other voltages evolved with the aid of S5, S6, and $\mathrm{S} 7$.

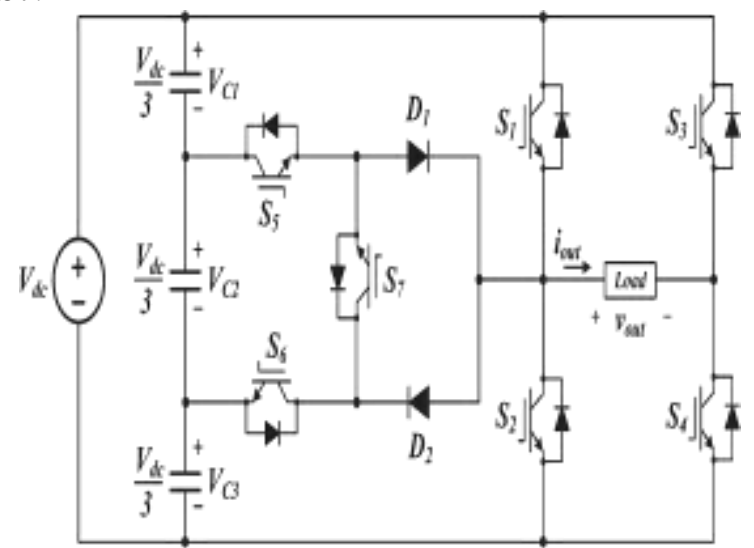

Fig. 1. Circuit configuration of the proposed sevenlevel PWM inverter.

\section{A. Modes Of Operation}

Level Vdc:

An electron path when the output voltage $\mathrm{i}$

$V$ dc. 3 capacitors coupled in series give energy to the load.It discharges from $\mathrm{S} 1$ to $S 4$. For inductive load, current direction is reversed, it is from DS1 to DS4, energises capacitor stack. 


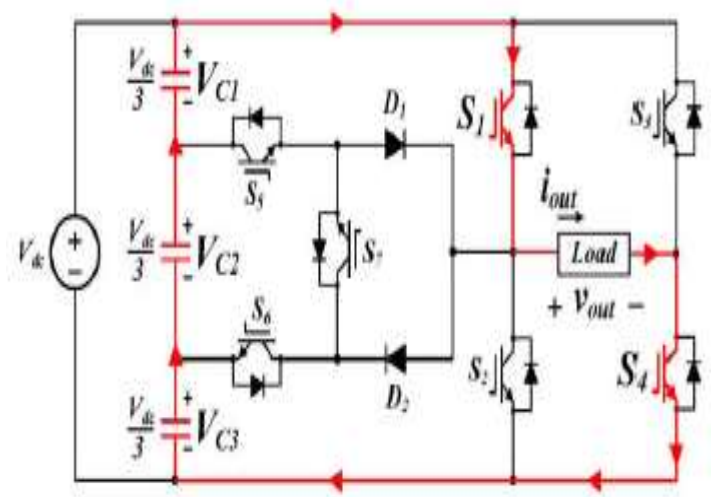

Fig. 2 (a) Circuit for obtaining Level Vdc

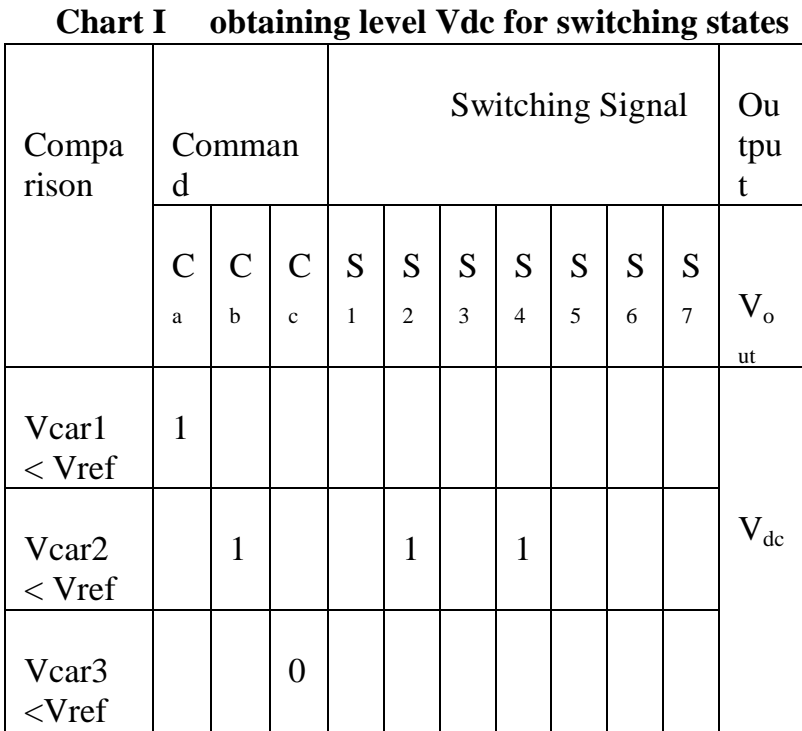

Level 2Vdc/3: The contemporary course after the weight voltage is 2VDC / 32 capacitors C2 and C3 feed output. It discharges through S5, D1, and S4. Once the burden present day path is opposite, there's no way right now underneath the country of this variation. At this point, the load contemporary flows thru the DS1 and DS4, and the price of strength pile condenser. Not with Standing load modern-day flows, the output voltage is clamped for 2VDC / 3 stages with state modifications.

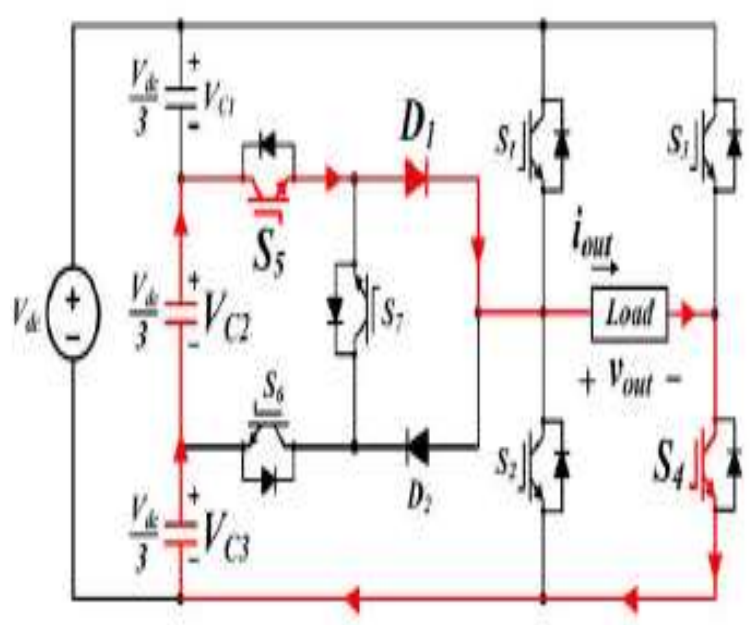

Fig. 2 (b) Circuit for obtaining Level 2 Vdc/3
TABLE II Switching states for obtaining level 2Vdc/3

\begin{tabular}{|c|c|c|c|c|c|c|c|c|c|c|c|}
\hline \multirow{2}{*}{ Comparison } & \multicolumn{3}{|c|}{ Command } & \multicolumn{7}{|c|}{ Switching Signal } & \multirow{2}{*}{$\begin{array}{c}\text { Output } \\
\mathrm{V}_{\text {out }}\end{array}$} \\
\hline & $\mathrm{C}_{\mathrm{a}}$ & $\mathrm{C}_{\mathrm{b}}$ & $\mathrm{C}_{\mathrm{c}}$ & $\mathrm{S}_{1}$ & $\mathrm{~S}_{2}$ & $\mathrm{~S}_{3}$ & $\mathrm{~S}_{4}$ & $\mathrm{~S}_{5}$ & $\mathrm{~S}_{6}$ & $\mathrm{~S}_{7}$ & \\
\hline $\begin{array}{l}\text { Vcar1 } \\
\text { Vref }\end{array}$ & 1 & & & & & & & & & & \multirow{3}{*}{$\frac{2}{3} \mathrm{~V}_{\mathrm{dc}}$} \\
\hline $\begin{array}{l}\text { Vcar2 < } \\
\text { Vref }\end{array}$ & & 1 & & & & & 1 & 1 & & & \\
\hline $\begin{array}{l}\text { Vcar3 > } \\
\text { Vref }\end{array}$ & & & 1 & & & & & & & & \\
\hline
\end{tabular}

Level Vdc/3:

A contemporary direction as soon as the output voltage is $\mathrm{Vdc} / 3$. The decrease finish condenser (C3) affords power to the output. It offers from DS6, S7, D1, and S4.If the course of the weight modern is opposite, the load current flows thru D2, S7, DS5, and DS4.

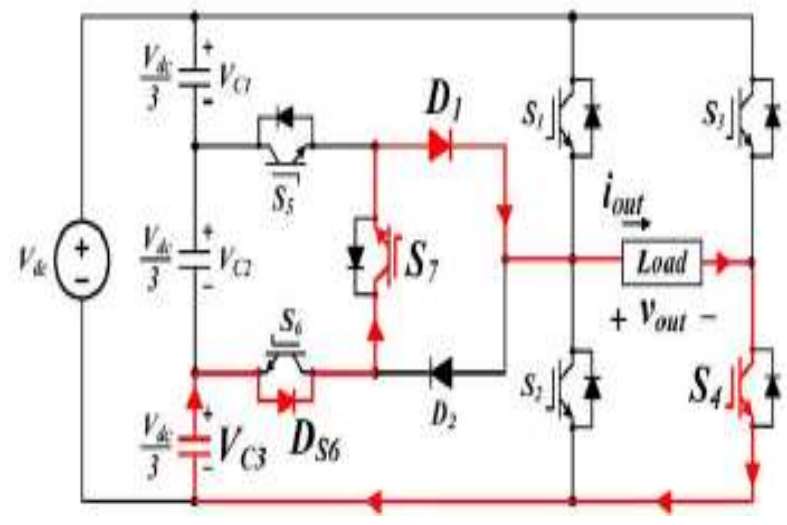

Figure. 2 (c) Circuit for obtaining Level Vdc/3

TABLE III Switching states for obtaining level Vdc/3

\begin{tabular}{|c|c|c|c|c|c|c|c|c|c|c|c|}
\hline \multirow{2}{*}{$\begin{array}{l}\text { Compariso } \\
\mathrm{n}\end{array}$} & \multicolumn{3}{|c|}{ Command } & \multicolumn{7}{|c|}{ Switching Signal } & \multirow{2}{*}{$\begin{array}{l}\text { Outpu } \\
\mathrm{t} \\
\mathrm{V}_{\text {out }}\end{array}$} \\
\hline & $\begin{array}{l}\mathrm{C} \\
\mathrm{a}\end{array}$ & $\begin{array}{l}\mathrm{C} \\
\mathrm{b}\end{array}$ & $\begin{array}{l}\mathrm{C} \\
\mathrm{c}\end{array}$ & $\begin{array}{l}\mathrm{S} \\
1\end{array}$ & $\begin{array}{l}\mathrm{S} \\
2\end{array}$ & $\mathrm{~S}$ & $\begin{array}{l}\text { S } \\
4\end{array}$ & $S$ & $\begin{array}{l}\mathrm{S} \\
6\end{array}$ & $\begin{array}{l}S \\
7\end{array}$ & \\
\hline $\begin{array}{l}\text { Vcar1 < } \\
\text { Vref }\end{array}$ & 1 & & & & & & & & & & \multirow{3}{*}{$\frac{1}{3} \mathrm{~V}_{\mathrm{dc}}$} \\
\hline $\begin{array}{l}\text { Vcar2 > } \\
\text { Vref }\end{array}$ & & 0 & & & & & 1 & & & 1 & \\
\hline $\begin{array}{l}\text { Vcar3 > } \\
\text { Vref }\end{array}$ & & & 1 & & & & & & & & \\
\hline
\end{tabular}

Level 0:

To produce 0 degrees, 2 -around scheme is expected to shift regularly. Plan's important to get the level of voltage zero cancellation. A moment after synthesizing the level 0 . After S2 and S4 turn on at the same time, the output voltage becomes zero.

Another technique is to turnS1 and S3 at the regular time. After the road when weight is on the contrary, can now be floated. Contrary to this day will go with the flow in $-\mathrm{V} \mathrm{dc} /$

Published By: 
3 degrees. (L) Opposite modern glides on -Vdc level

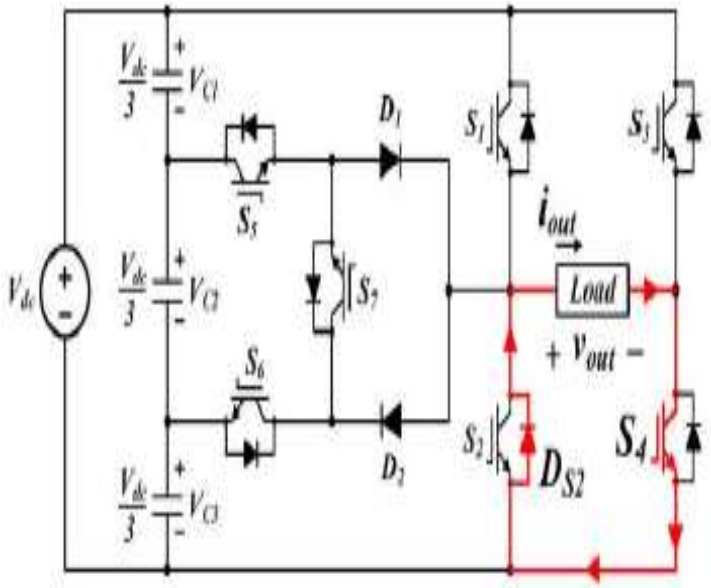

Fig. 2 (d) Circuit for obtaining Level 0

Table IV Switching states for obtaining level 0

\begin{tabular}{|c|c|c|c|c|c|c|c|c|c|c|c|}
\hline \multirow{2}{*}{$\begin{array}{l}\text { Compari } \\
\text { son }\end{array}$} & \multicolumn{3}{|c|}{ Command } & \multicolumn{7}{|c|}{ Switching Signal } & \multirow{2}{*}{$\begin{array}{l}\text { Outp } \\
\text { ut }\end{array}$} \\
\hline & $\mathrm{C}$ & $\begin{array}{l}\mathrm{C} \\
\mathrm{b}\end{array}$ & $\mathrm{C}$ & $\begin{array}{l}S \\
1 \\
\end{array}$ & $\begin{array}{l}S \\
2\end{array}$ & $\begin{array}{l}S \\
3\end{array}$ & $\begin{array}{l}S \\
4 \\
\end{array}$ & $\begin{array}{l}S \\
5\end{array}$ & $\begin{array}{l}S \\
6 \\
\end{array}$ & $\begin{array}{l}S \\
7\end{array}$ & \\
\hline $\begin{array}{l}\text { Vcar1 > } \\
\text { Vref }\end{array}$ & 0 & & & & & & & & & & \multirow{3}{*}{0} \\
\hline $\begin{array}{l}\text { Vcar2 > } \\
\text { Vref }\end{array}$ & & 0 & & & 1 & & 1 & & & & \\
\hline $\begin{array}{l}\text { Vcar3 > } \\
\text { Vref }\end{array}$ & & & 1 & & & & & & & & \\
\hline
\end{tabular}

Level-Vdc/3: A electric current path once it generates the $-\mathrm{Vdc} / 3$ level. The higher condenser $(\mathrm{C} 1)$ provides energy to the load. If the direction of the output current is reverse.

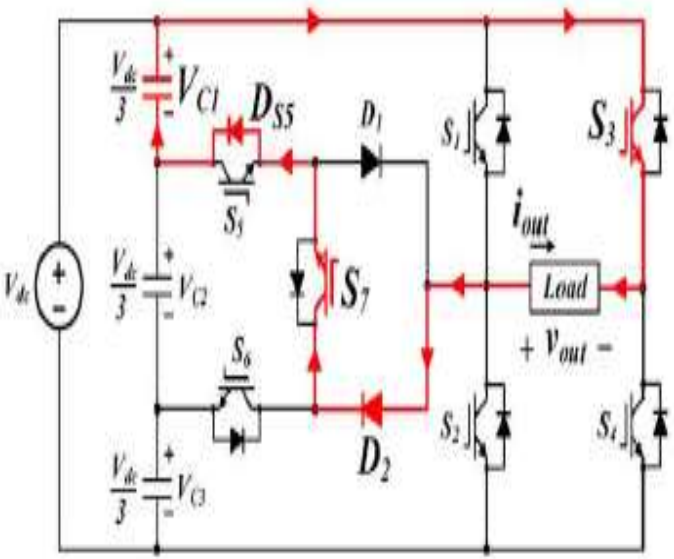

Fig. 2 (e) Circuit for obtaining Level - Vdc/3

\begin{tabular}{|c|c|c|c|c|c|c|c|c|c|c|c|}
\hline \multirow{2}{*}{ Comparison } & \multicolumn{3}{|c|}{ Command } & \multicolumn{7}{|c|}{ Switching Signal } & \multirow{2}{*}{$\frac{\text { Output }}{\mathrm{V}_{\text {out }}}$} \\
\hline & $\mathrm{C}_{\mathrm{a}}$ & $\mathrm{C}_{\mathrm{b}}$ & $\mathrm{C}_{\mathrm{c}}$ & $S_{1}$ & $\mathrm{~S}_{2}$ & $\mathrm{~S}_{3}$ & $\mathrm{~S}_{4}$ & $\mathrm{~S}_{5}$ & $\mathrm{~S}_{6}$ & $\mathrm{~S}_{7}$ & \\
\hline $\begin{array}{l}\text { Vcar1 < } \\
\text { Vref }\end{array}$ & 1 & & & & & & & & & & \multirow{3}{*}{$-\frac{1}{3} \mathrm{~V}_{\mathrm{dc}}$} \\
\hline $\begin{array}{l}\text { Vcar2 } \\
\text { Vref }\end{array}$ & & 0 & & & & 1 & & & & 1 & \\
\hline $\begin{array}{l}\text { Vcar3 > } \\
\text { Vref }\end{array}$ & & & 1 & & & & & & & & \\
\hline
\end{tabular}

Level $-2 \mathrm{Vdc} / 3$ :

A pit road after volts across the load is 2VDC / 32 capacitors $\mathrm{C} 1$ and $\mathrm{C} 2$ to offer power to the destination. After the load current reverses, flowing from DS2 to DS3.Inspite output current flows, voltage support level load $-2 \mathrm{Vdc} / 3$ by the state shifts.

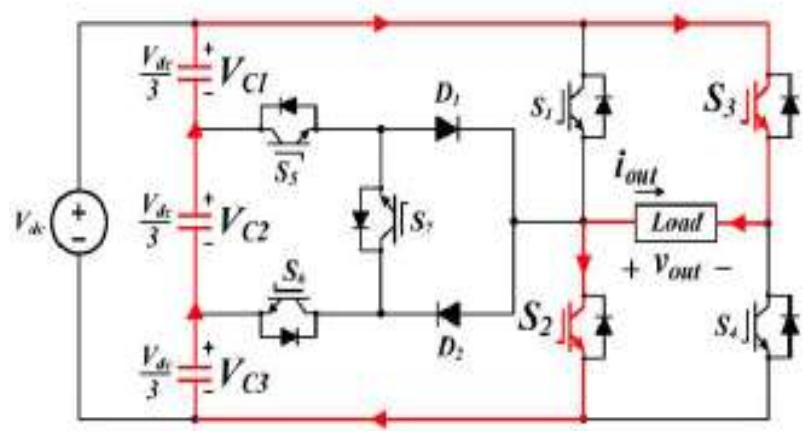

Fig. 2 (f) Circuit for obtaining Level - 2Vdc/3

Table Vi Switching states for obtaining level $-2 \mathrm{Vdc} / 3$

\begin{tabular}{|c|c|c|c|c|c|c|c|c|c|c|c|}
\hline \multirow{2}{*}{$\begin{array}{l}\text { Compa } \\
\text { rison }\end{array}$} & \multicolumn{3}{|c|}{$\begin{array}{l}\text { Comman } \\
\text { d }\end{array}$} & \multicolumn{7}{|c|}{ Switching Signal } & \multirow{2}{*}{$\begin{array}{l}\begin{array}{l}\text { Out } \\
\text { put }\end{array} \\
\mathrm{V}_{\text {out }}\end{array}$} \\
\hline & $\mathrm{C}$ & $\begin{array}{l}\mathrm{C} \\
\mathrm{b} \\
\end{array}$ & $\mathrm{C}$ & S & $\begin{array}{l}\mathrm{S} \\
2 \\
\end{array}$ & $\begin{array}{l}\mathrm{S} \\
3 \\
\end{array}$ & $\begin{array}{l}\mathrm{S} \\
4 \\
\end{array}$ & $\begin{array}{l}\mathrm{S} \\
5 \\
\end{array}$ & $\begin{array}{l}S \\
6 \\
\end{array}$ & $\begin{array}{l}S \\
7 \\
\end{array}$ & \\
\hline $\begin{array}{l}\text { Vcar1 } \\
<\text { Vref } \\
\end{array}$ & 1 & & & & & & & & & & \multirow{3}{*}{$\begin{array}{l}\frac{-}{3} \mathrm{~V}_{\mathrm{d}} \\
\mathrm{c}\end{array}$} \\
\hline $\begin{array}{l}\text { Vcar2 } \\
<\text { Vref } \\
\end{array}$ & & 1 & & & & 1 & & & 1 & & \\
\hline $\begin{array}{l}\text { Vcar3 } \\
>\text { Vref }\end{array}$ & & & 1 & & & & & & & & \\
\hline
\end{tabular}

Level $-V d c$ :

A electrons path once the destination voltage is 2Vdc/3. 2 capacitors $\mathrm{C} 1$ and $\mathrm{C} 2$ offer joule to the output load. once the load current reverses, it flows through DS2 and DS3. Regardless of the load current flows, the output voltage sustains the $-2 \mathrm{Vdc} / 3$ level by the shift state. 


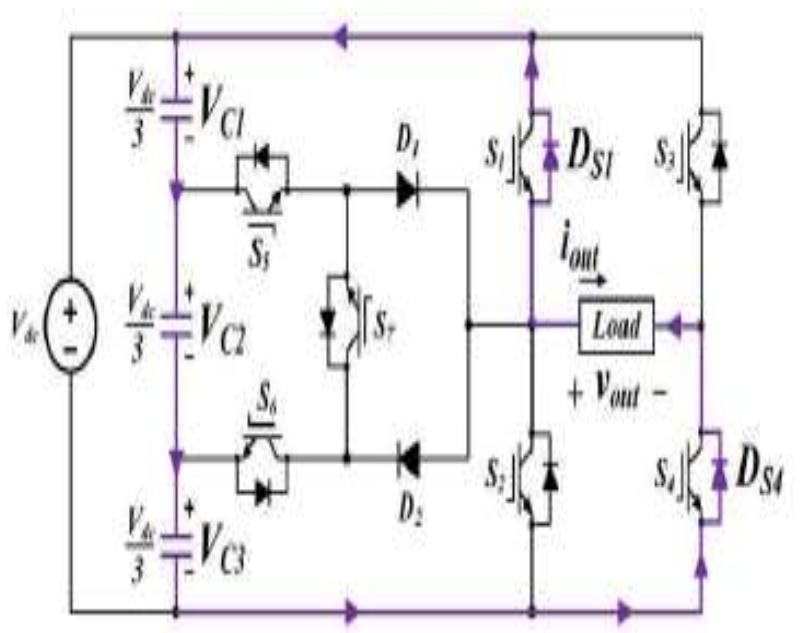

Fig. 2 (g) Circuit for obtaining Level - Vdc

TABLE VII Switching states for obtaining level -Vdc

\begin{tabular}{|c|c|c|c|c|c|c|c|c|c|c|c|}
\hline \multirow{2}{*}{$\begin{array}{l}\text { Compari } \\
\text { son }\end{array}$} & \multicolumn{3}{|c|}{ Command } & \multicolumn{7}{|c|}{ Switching Signal } & \multirow{2}{*}{$\begin{array}{l}\begin{array}{l}\text { Outp } \\
\text { ut }\end{array} \\
\mathrm{V}_{\text {out }}\end{array}$} \\
\hline & C & C & $\mathrm{C}$ & $S$ & $\mathrm{~S}$ & $\mathrm{~S}$ & $\begin{array}{l}S \\
4\end{array}$ & S & S & S & \\
\hline $\begin{array}{l}\text { Vcar1 } \\
\text { Vref }\end{array}$ & 1 & & & & & & & & & & \\
\hline $\begin{array}{l}\text { Vcar2< } \\
\text { Vref }\end{array}$ & & 1 & & & 1 & 1 & & & & & $-\mathrm{V}_{\mathrm{dc}}$ \\
\hline $\begin{array}{l}\text { Vcar3< } \\
\text { Vref }\end{array}$ & & & 0 & & & & & & & & \\
\hline
\end{tabular}

\section{B. General SwitchingScheme}

Table I - VII lists the switching patterns for generating seven output voltage levels. By comparing there ference and each carrier wave, it produces command signals $(\mathrm{Ca}, \mathrm{Cb}$, and $C c)$.

\section{Capacitor voltage unbalance}

The voltage reconciliation of series-connected condenser acting as associate energy barrel is extremely necessary to get precise output voltage levels within the planned structure electrical converter. Fig.3(a) shows the equivalent circuit of the 7- level electrical converter. Fig. 3(b) describes the stepped output voltage and also the insulation load current.

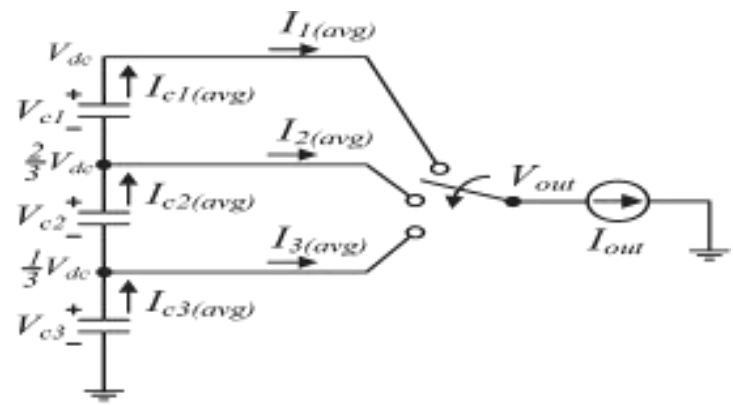

(a)

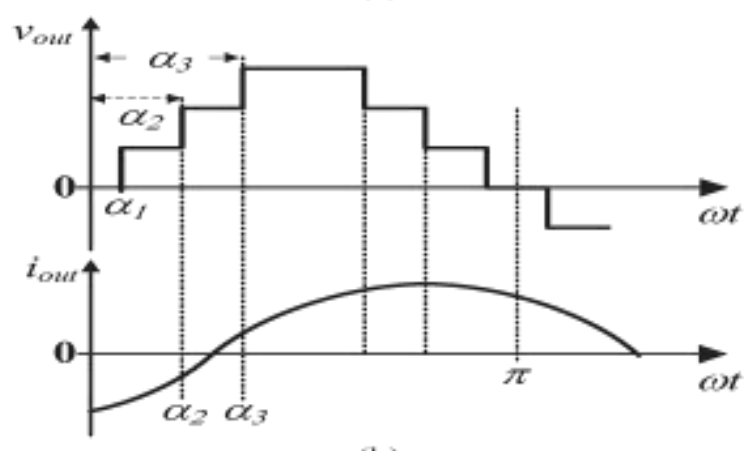

(b)

Fig. 3. Equivalent circuit of the model with waveforms.

Based on the equivalent circuits and capacitor charging equation it could be seen that the voltage imbalance happens as the impact of varying the angle switching. The courting between the charging modern-day and the switching angle is given by way of the subsequent equation

$\mathrm{IC} 1$ (avg) = IC2(avg)=IC3(avg). (1)

\section{Scheme for Voltage Balancing}

To cope with the imbalance voltage electrical devices, we generally tend to introduce modifications to the projected pattern of change inside the improvement of an electric converter. Maximum plans are projected control method is to manipulate the charge of charging and discharging of the electrical tool C2. This guarantees the voltage regulation of $\mathrm{C} 2$ and additionally balance the voltage of the capacitor is better and lower. Because of putting between $\mathrm{C} 1 \mathrm{C} 2$ and $\mathrm{C} 3$, the charging and discharging of $\mathrm{C} 1$ and $\mathrm{C} 3$ ought to drift via $\mathrm{C} 2$. Thus, the voltage law of $\mathrm{C} 2$ is directly related to the voltage regulation $\mathrm{C} 1$ and $\mathrm{C} 3$.Changed control techniques to control voltage $\mathrm{C} 2$.

$\mathrm{vcar}_{1} \max =\mathrm{vcar}_{2} \min \leq \Delta \mathrm{vcar} 2$

$\leq$ vcar $_{2} \_$max $=$vcar $_{3}$ max (2)

Control signal Cbchanges its obligation proportion predictable with the particular amplitudes of vcar2. The duty proportion of Cbis immediately identified with the obligation proportions of S5 and S7 for the $+2 \mathrm{Vdc} / 3$ degree innovation. When $\mathrm{S} 5$ initiates the yield voltage becomes $+2 \mathrm{Vdc} /$ three. This period is a releasing time of $\mathrm{C} 2$. On the contrary hand, while S5 kills and S7 turns on, as the yield voltage stage will become $+\mathrm{Vdc} /$ three, which allows the charging of $\mathrm{C} 2$. Two assistance waves which have exceptional amplitudes ,i.E., $\mathrm{Vp}, 1$ and $\mathrm{Vp}, 2$, separately. 
The waveform in Fig 4 recommends the various time interims for the span of that the switches rectangular degree became on and stale. The amount forevery move is set upheld the move technique. We will be slanted to accept that the supplier recurrence is shockingly unreasonable just so the adequacy of the continuous convergences of the reference and thusly the radio wave at positions $\theta \mathrm{i}$ and $\theta * \mathrm{i}$ is predictable.
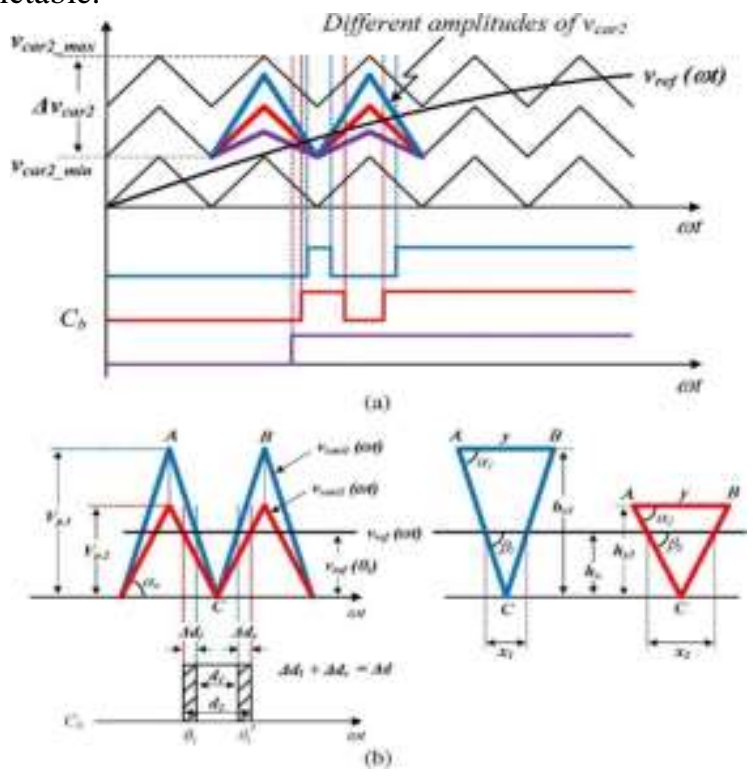

Fig. 4. Modified control scheme for capacitor voltage balancing.

\section{SIMULATION AND EXPERIMENTAL RESULTS}

\section{A. Simulation Results}

To check the legitimacy of the anticipated seven-level 4PWM electrical converter,we dispensed PC supported recreations exploitation MATLAB and experimentsusing a picture of one power unit. The info dc voltage is going to dc150V; in this way, every condenser voltage is part into 3 fifty $\mathrm{V}$ in an ideal case. The recurrence is going to be fifty cycle for every second. The determinations of the reproduction is given in table VIII. The reenactment graph is appeared in Fig about six and in this way the move topic execution is appeared inside the figure seven. The yield voltage waveforms of the reproduction circuit is appeared in figure eight.

Table VIII Simulation circuit parameters

\begin{tabular}{|l|l|}
\hline Parameter & Range \\
\hline Input voltage $\mathrm{V}_{\mathrm{dc}}$ & $150 \mathrm{~V}$ \\
\hline Output Voltage $\mathrm{V}_{\text {out }}$ & $110 \mathrm{~V}, 50 \mathrm{~Hz}$ \\
\hline $\begin{array}{l}\text { Carrier wave frequency } \\
\text { fs }\end{array}$ & $10 \mathrm{KHz}$ \\
\hline Capacitor $\mathrm{C}_{1}, \mathrm{C}_{2}, \mathrm{C}_{3}$ & $1100 \mu \mathrm{F}$ \\
\hline LC Filter $\mathrm{L}_{0}$ and $\mathrm{C}_{0}$ & $8 \mathrm{mH}$ and $2.2 \mu \mathrm{F}$ \\
\hline
\end{tabular}

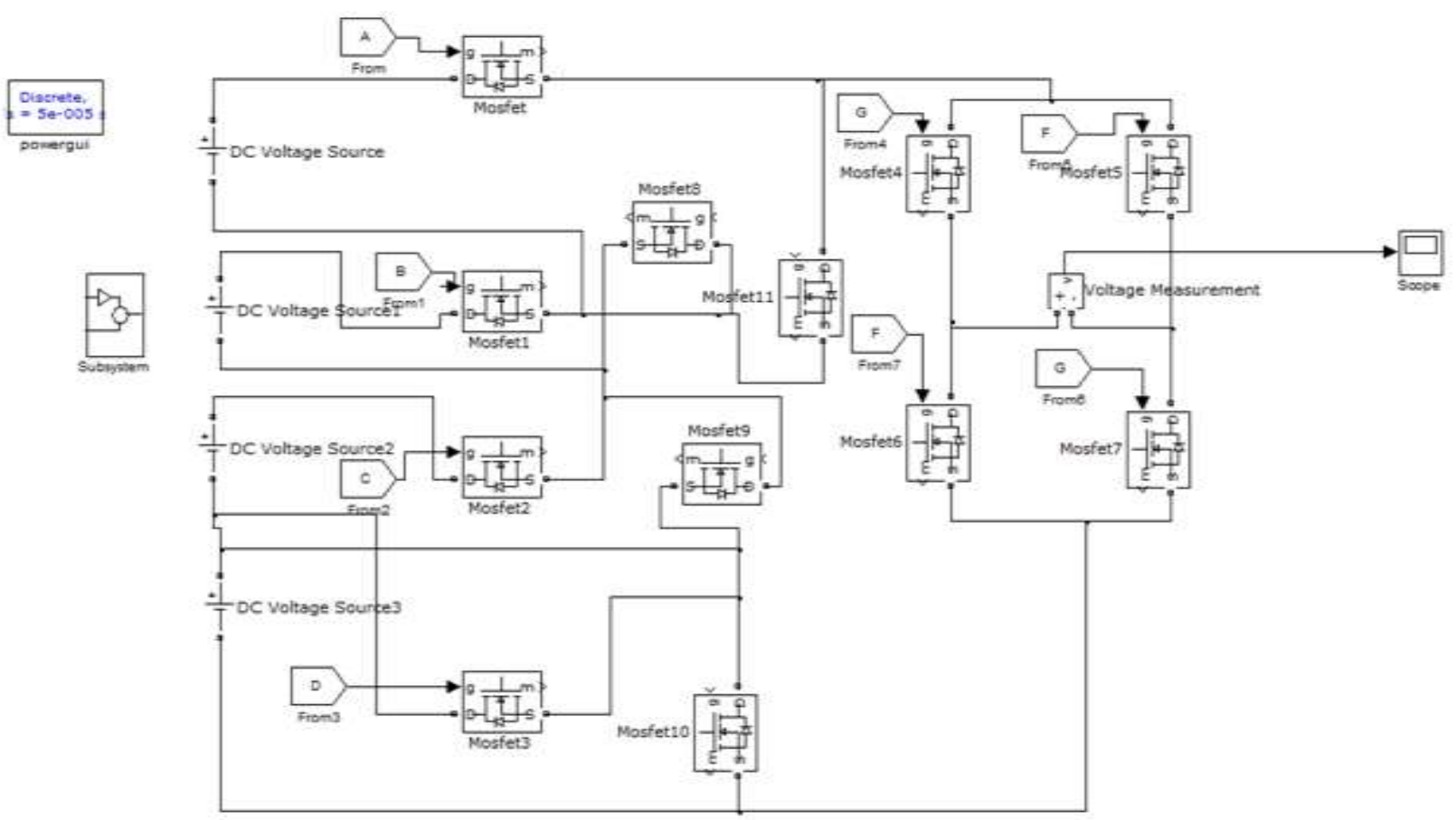

Fig. 6. Simulation circuit of the proposed simplified seven level PWM inverter 


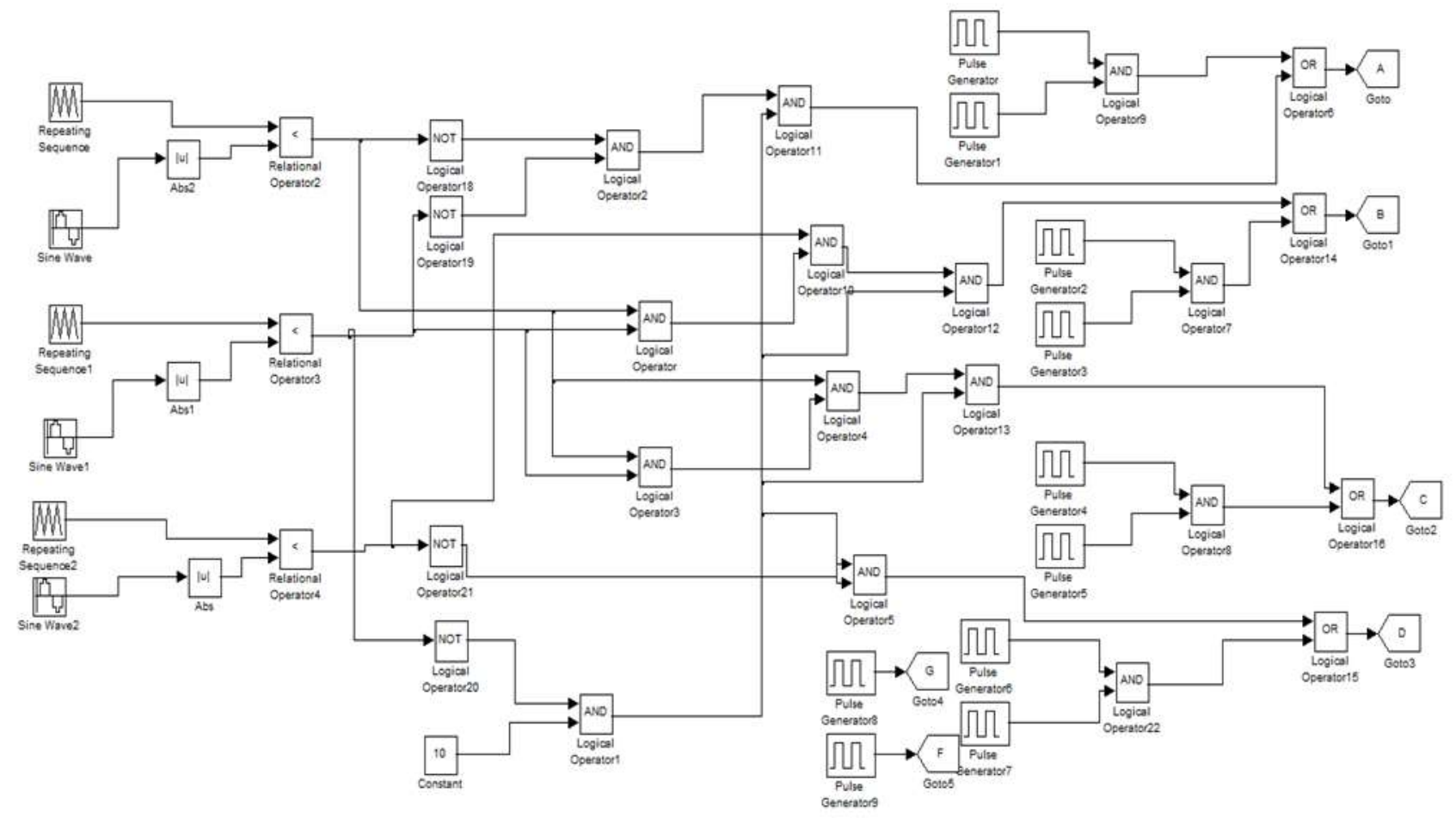

Fig. 7. Simulation circuit of the proposed switching scheme

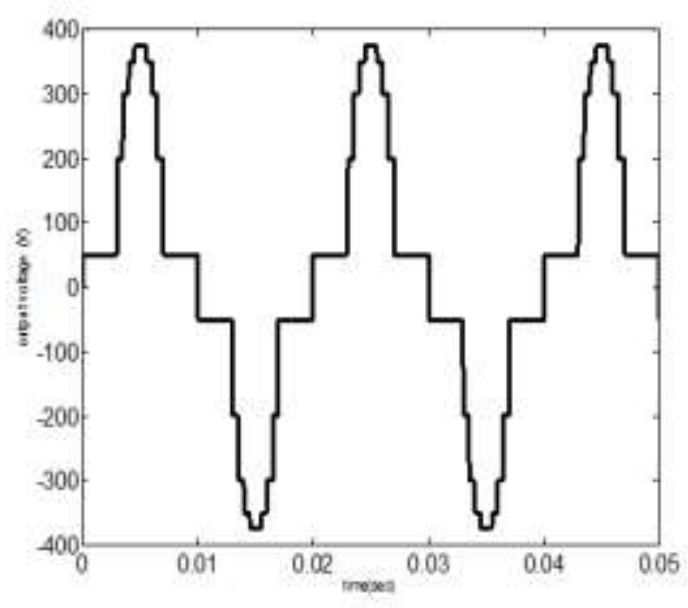

Fig. 8. Output voltage waveform

The output voltage undulation proven in Fig. Eight multistepped undulations may additionally as a consequence decreasing the decrease order harmonic factors. The lower order harmonics or the dominant unit vicinity is hard to do away with on account that

dimensions of filter needed is giant.

Table IX Comparison Of Number Of Circuit Components

\begin{tabular}{|l|l|l|l|l|}
\hline $\begin{array}{l}\text { No. of } \\
\text { components }\end{array}$ & FC & DC & CH & Proposed \\
\hline Switch & 12 & 12 & 12 & 7 \\
\hline Diode & 0 & 6 & 0 & 2 \\
\hline Capacitor & 6 & 3 & 3 & 3 \\
\hline $\begin{array}{l}\text { Input DC } \\
\text { source }\end{array}$ & 1 & 1 & 3 & 1 \\
\hline
\end{tabular}

In Table IX, the quantity of circuit additives required to make a seven-level electric converter for designs shift checked out. Flying capacitor (FC), Diode-cinched (DC), Cascaded H-Bridge $(\mathrm{CH})$ contrasted with the customary layout of the system is expected. From the exam evidently the projection framework needs much less assortment of components.

\section{CONCLUSION}

In this paper a fundamental style of staggered tempo of 7 arranged electric converter, which utilizes only a solitary voltage deliver viable to increase the amount of yield voltage tiers. We will in trendy association electrical converter PWM structure which might viably extend the quantity of stages of yield voltage with a dc voltage deliver. To blend the yield voltage of the seven tiers, the arranged structure electrical converter need a dc supply voltage with subsidiaries association of three capacitors, diodes, 3 dynamic alternate to orchestrate the yield voltage degree, cellular ANd H-connect. At the factor when the hypothetical investigation, we will in general energy-helped undertaking authorized PC to check the legitimacy of an arranged methodology. Here, we are able to in wellknown acquaint the topic modified with reveal transfer unbalancingthat voltage happens in the arrangement related capacitors. We can in widespread think about the quantity of number one regions, the commotion voltage on the machine transfer, and an inverter the beyond shape. Accordingly, we can in popular assure that the arranged seven-degree PWM electrical converter would be a suitable applicant, that can 
supplant commonplace PWM inverter in the energy score of a run of the mill use.

\section{REFERENCE}

1. M.F.KangarluandE.Babaei,

"Ageneralizedcascadedmultilevelinverter use submultilevel arrangement affiliation of inverters," IEEE Trans. Power Electron., Vol.28, No.2, pp.625-636, Feb.2013.

2. A. Mokhberdoran and A. Ajami, "Symmetric and topsyturvy andimplementationofnewcascadedmultilevelinvertertopol ogy plan," IEEE Trans.PowerElectron., Vol.29, no.12, pp.6712-6724, Dec.2014.

3. S. Gautam and R. Gupta, "willpower Switching recurrence for cas-caded staggered inverter works within the manipulate mode whilst making use of multibandhysteresismodulation," IEEETrans.PowerElectron., Vol.29, No. Three, pp. 1480-1489, Mar.2014. 